\title{
Observational study of PTH secretion dynamics in patients with secondary hyperparathyroidism
}

N.Karlovich

Belarusian State Medical University, Minsk, Belarus

\section{OBJECTIVES}

The aim was to analyze dynamics of PTH secretion in dialysis patients during different period of observation and to determine factors of secondary hyperparathyroidism progression.

\section{METHODS}

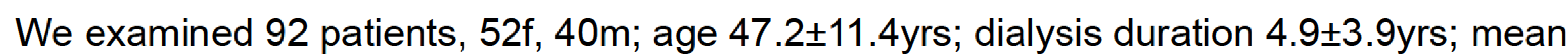
observational period $8.9 \pm 4$.3months (6-24). Serum PTH, 25(OH)D3, osteocalcin (OC), Cterminal telopeptide of type I collagen (beta-CTx), alkaline phosphotase (ALP), calcium (Ca) and phosphorus $(P)$ were measured initially and at the end of observation. All patients were recommended to follow low-phosphate diet and $74.4 \%$ received calcium carbonate.

\section{RESULTS}

PTH level was $559.6 \pm 552.5$ initially and $603.9 \pm 581.6 \mathrm{pg} / \mathrm{ml}$ at the end of observation, $\mathrm{p}=0.251$.

Frequency of high, normal uremic and low PTH levels was $55.4 \%$ vs $57.6 \%, 20.7 \%$ vs $21.7 \%, \quad 23.9 \%$ vs $20.7 \%$, respectively $(p>0.05)$.

Serum phosphorus decreased from $2.34 \pm 0.67$ to $2.14 \pm 0.60 \mathrm{mmol} / \mathrm{l}, \mathrm{p}=0.0003$.

In patients with initial hypercalcemia $\mathrm{PTH}$ increased from 525.3 \pm 518.4 to $616.2 \pm 606.2 \mathrm{pg} / \mathrm{ml}, \mathrm{p}=0.03$.

$\mathrm{PTH}$ level at the end of observation correlate with age $(r=-0.25)$, OC $(r=0.58)$, beta-CTx $(r=0.76)$ and ALP $(r=0.40)$. Strong correlation was found with the initial PTH ( $r=0.84)$.

At the end of observation PTH decreased in 40pts $(43.5 \%)$, mean decrease $204.6 \pm 250.1 \mathrm{pg} / \mathrm{ml}$; increased in $52 \mathrm{pts}$ $(56.5 \%)$, mean increase $235.6 \pm 274.5 \mathrm{pg} / \mathrm{ml}$. Subgroups with decreased and increased PTH didn't show differences of demographic data, levels of $\mathrm{Ca}, \mathrm{P}$ and bone turnover markers.

Comparison of initial and repeated PTH level in subgroups with duration of observation $6 \mathrm{~m}$, $9 \mathrm{~m}, 12 \mathrm{~m},>12 \mathrm{~m}$ didn't,, reveal significant changes

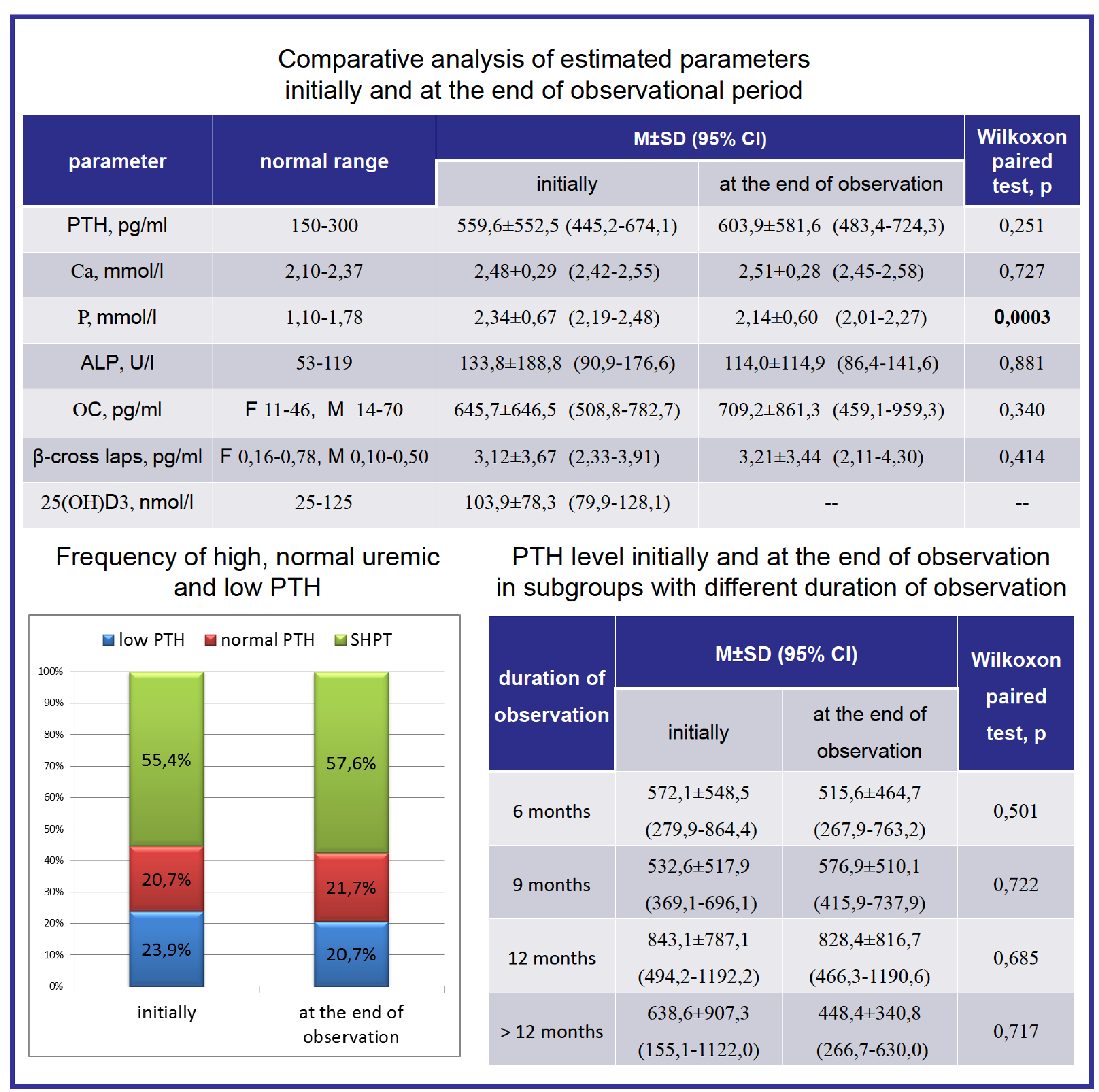

\section{References}

Felsenfeld A.J., Rodrıguez M., Aguilera-Tejero E. Dynamics of Parathyroid Hormone Secretion in Health and Secondary Hyperparathyroidism // Clin J Am Hormone Secretion in Health and Seco

2. Kidney Disease: Improving Global Outcomes (KDIGO) CKD-MBD Work Group. KDIGO clinical practice guideline for the diagnosis, evaluation, prevention, and KDIGO clinical practice guideline for the diagnosis, evaluation, prevention, an
treatment of chronic kidney disease-mineral and bone disorder (CKD-MBD). treatment of chronic kidney disease-mineral and bone

Kidney International 2009; 76 (Suppl 113): S1-S130.
3. Moe S.M., Drueke T., Lameire N., Eknoyan G. Chronic kidney disease mineral-bone disorder: a new paradigm // Adv Chronic Kidney Dis. - 2007. Vol. 14(1). - P. 3-12.

4. National Kidney Foundation Dialysis Outcomes Quality Initiative (K/DOQI) guidelines //

http://www.kidney.org/professionals/kdogi/guidelines bone/index.htm 5. Wei M., Taskapan H., Esbaei K., Jassal S.V., Bargman J.M., Oreopoulos D.G. KIDOQ guideline requirements for calcium, phosphate, calcium phosphate product, and parathyroid hormone control in dialysis patients: can we achieve them? // Int Urol Nephrol. 2006; 38(3-4): P. 739-743. 